\title{
Green Synthesis, Optimization, and Characterization of Silver Nanoparticles from Euphorbia rigida Leaf Extract and Investigation of Their Antimicrobal Activities
}

\author{
Euphorbia rigida Yaprak Ekstraktından Gümüș \\ Nanopartiküllerin Yeşil Sentezi, Optimizasyonu ve \\ Karakterizayonu ve Antimikrobiyal Aktivitelerinin Araştırılması
}

Geliş / Received: 18/12/2020

\author{
Ebru Kocadağ Kocazorbaz ${ }^{*}$
}

Revize / Revised: 08/02/2021

Kabul / Accepted: 04/03/2021

\begin{abstract}
Green synthesis is a biological method known for being environment-friendly, cheap and for retrieval of nanoparticles with ease, which is preferred more than chemical and physical methods. Various metallic nanoparticles with potent bioactivities have been synthesized using plant extracts. In this study, synthesis of silver nanoparticles (AgNPs) using the aqueous leaf extract of Euphorbia rigida was investigated. Their antibacterial activity was determined using microdilution methods. The optimization of the synthesis was performed via the adjustment of different parameters including $\mathrm{pH}$, temperature, concentration of the plant extract, the different concentrations of $\mathrm{AgNO}_{3}$, and synthesis time using UVvisible spectroscopy. Silver nanoparticles (Er-AgNPs) that were synthesized by Euphorbia rigida characterized by Dynamic Light Scattering (DLS) and Scanning Electron Microscope (SEM) analyses and their antimicrobial potential were tested on six different pathogens. The synthesis process resulted in spherical-shaped NPs with a size ranging between 50-75nm. The AgNPs demonstrated a strong antimicrobial activity against various pathogens (Escherichia coli, Staphylococcus aureus, Enterococcus faecium, Staphylococcus epidermidis, Salmonella enteritidis, Salmonella typhimurium, Listeria monocytogenes and Candida albicans). The results showed that the synthesized Er-AgNPs can be used as a biological material for biomedical, pharmaceutical, biotechnology and industrial areas. In this study, the antimicrobial potential of silver nanoparticles which are prepared using Euphorbia rigida leaf extract isreported for the first time.
\end{abstract}

Keywords- Antimicrobial Activity, Dynamic Light Scattering, Euporbia Rigida, Scanning Electron Microscope, Silver Nanoparticle

$\overline{\mathbf{O Z Z}}$

Yeşil sentez; çevre dostu ve maliyet açısından ucuz olması, kimyasal ve fiziksel yöntemlerden daha çok tercih edilen nanopartiküllerin kolay bir şekilde elde edilmesi ile bilinen biyolojik bir yöntemdir. Potansiyel biyolojik aktiviteye sahip çeşitli metallik nanopartiküller bitki özütleri kullanılarak sentezlenmektedir. Bu çalışmada, sütleğengil (Euphorbia rigida) yaprak sulu özütü kullanılarak, yeşil sentez yöntemi ile gümüş nanopartikülleri (AgNP) sentezlendi. Sentezlenen nanpartikülerin antimikrobiyal aktiviteleri mikrodilüsyon yöntemi ile belirlendi.Yeşil sentezin optimizasyonu, sıcaklık, $\mathrm{pH}$, sentez zamanı, $\mathrm{AgNO}_{3}$ ve bitki özütünün farklı konsantrasyonları gibi farklı parametrelerin denenmesi ile gerçekleştirildi. Euphorbia rigida yaprak özütünden sentezlenen gümüş nanopartiküller (Er-AgNPs), Ultraviyole/görünür 1şık absorbsiyon spektrofotometresi (Uv-

${ }^{1 *}$ Sorumlu yazar iletişim: kocadage@hotmail.com (https://orcid.org/0000-0001-5611-5235)

Faculty of Science, Biochemistry Department, Ege University, Izmir 
vis), Dinamik ışık saçılımı (DLS), Taramalı Elektron Mikroskobu (SEM) analizleri ile karakterize edildi. Altı farklı patojene karşı antimikrobiyal aktiviteleri belirlendi. Bu çalı̧̧ada, Euphorbia rigida bitkisinin yaprak özütüne ait örneğin parçacık boyutunun histogramının 50 ile $75 \mathrm{~nm}$ olan küresel yapılı Ag nanopartiküller sentezlendi. Er-AgNPs'ler çeşitli patojenlere (Escherichia coli, Staphylococcus aureus, Enterococcus faecium, Staphylococcus epidermidis, Salmonella enteritidis, Salmonella typhimurium, Listeria monocytogenes and Candida albicans) karşı güçlü bir antimikrobiyal aktivite gösterdi. Sonuç olarak, sentezlenen Er-AgNPs biyomedikal, farmasötik, biyoteknoloji ve endüstriyel alandaki uygulamalar için biyolojik bir materyal olarak kullanılabilir. Bu çalışmada, ilk kez Euphorbia rigida yaprak özütü kullanılarak hazırlanan gümüş nanopartiküllerin antimikrobiyal aktivitesi belirlendi.

\section{Anahtar Kelimeler- Antimikrobiyal Aktivite, Dinamik Işık Saçılımı, Euporbia Rigida, Taramalı Elektron Mikroskobu, Gümüş Nanopartikül}

\section{INTRODUCTION}

A nanoparticle is a microscopic particle with size ranging from 10 to $1000 \mathrm{~nm}$. Nanotechnology is a field of science that has a wide range of applications in biomedical sciences, pharmacology, food packaging materials, and personal care products, as well as its use as catalysts, drug carriers, and pollutants. In recent years, the field of nanotechnology has developed tremendously in terms of scientific research and applications [1]. The synthesis of nanoparticles was carried out by chemical, physical, and biological methods [2]. The synthesis of nanoparticles by biological method provides superiority to physical and chemical methods due to its low cost, simplicity of process, less chemical use, less energy requirement, and environmental friendliness [3]. Recently, many approaches by biological synthesis method have been developed to synthesize different nanoparticles. Fungi, bacteria, algae, yeast, and different green resources, such as plants are used for the synthesis of nanoparticles. Various methods, such as chemical reduction, ultrasonic radiation, laser ablation, evaporative cooling, sol-gel, microwave irradiation, photo reduction, thermal decomposition, and biological synthesis have been used to synthesize silver nanoparticles. Bacteria, fungi, actinomycetes, algae, and plant extracts are used for the synthesis of silver nanoparticles (AgNP) by biological method. Application areas of silver nanoparticles areagriculture, textile industry, cosmetics, food industry, as well as biosensor, catalyst in chemical reactions, optical receptor in nonlinear optics, antimicrobial agent, antiseptic for medical devices, and water disinfection. Silver nanoparticles have attracted more attention among metallic nanoparticles because of their various biological activities, including antioxidant, antibacterial, anticancer, antiinflammatory, antimicrobial and antifungal [4]. Euphorbia is the largest genus among Euphorbiaceae family, consisting of laticiferous plants. Euphorbiais represented by 106 species, with subspecies and variety total 116 taxa, 13 taxa of which are endemic and endemism ratio is near $9 \%$ in Turkey. Some Euphorbia species are used in the treatment of skinproblems, cancer, wounds, migraines, and worms. Compounds isolated from the genus Euphorbia and its extracts have protective, cytotoxic, antimicrobial, antiinflammatory, anticanceri, and antioxidant effects [5]. To our knowledge, there have been no reports of AgNPs synthesis using Euphorbia rigidaleaf aqueous extract (E.rigida) as a reducing agent. The present study aimed to use E.rigidafor the synthesis of AgNPs and evaluate the biological activities of the prepared nanoparticles. The leaf extract was first analyzed for its content using different biochemical methods. The synthesis process was optimized depending on time, temperature, and concentrations. The prepared NPs were characterized by UV-Vis spectral analysis, dynamic light scattering (DLS), and scanning electron microscopy (SEM). Lastly, the AgNPs were tested for their antimicrobial effect over different pathogen strands.

\section{MATERIALS AND METHODS}

\section{A. Preparation of Euphorbia rigida Leaf Aqueous Extract}

Euphorbia rigida (Euphorbiaceae) was used as a source in this study. Euphorbia rigida (E.rigida) plant samples were obtained by the Department of Botany of the Department of Biology of the Ege University. The green leaves of the plant were collected, cleaned with distilled water. The leaves were then left for drying at room temperature. The dried leaves were pulverized by pasting in mortar (Retsch ${ }^{\mathrm{TM}}$ RM 200 Mortar). Then 10 gr E.rigida leaves mixed with $100 \mathrm{~mL}$ distilled water then, boiled for $30 \mathrm{~min}$ at $90^{\circ} \mathrm{C}$. The extract solution was left 
to cool at room temperature and centrifuged at $10000 \mathrm{rpm}$ for $20 \mathrm{~min}$. The resulting E.rigida aqueous leaf extract filtered with Whatman No.1strainer paper and stored in refrigerator at $+4{ }^{\circ} \mathrm{C}$ in dark glass bottle for use as stock solution.

\section{B. Phytochemical Analysis of Euporbia rigida Leaf Extract Content} methods [6].

Phytochemical screening analyses of E.rigida aqueous extract were made by standard biochemical

\section{Total Phenolic Compound Determination}

The total phenolic compound content of plant extracts was determinedby the spectrophotometric method according to the phenol reaction of Folin-Ciocalteu [7]. Briefly, $100 \mu \mathrm{L}$ of E.rigida leaf extract was mixed with $1 \mathrm{~mL}$ Folin- Ciocalteu reagent $(10 \%)$ then, the mixture was incubated in the dark for 5 min at room temperature. After, sodium carbonate $\left(\mathrm{Na}_{2} \mathrm{CO}_{3}, 7.5 \%, 800 \mu \mathrm{L}\right)$ was added. The solutions were left for 60 min. and their absorbance was measured with a UV-Vis. spectrophotometer at $760 \mathrm{~nm}$. Gallic acid $(5-100 \mu \mathrm{g} / \mathrm{mL})$ was used as a standard. The samples were repeated 3 times for each analysis and the total phenolic content was calculated as $\mu \mathrm{g} / \mathrm{mL}$ gallic acid equivalent ( $\mu \mathrm{g} / \mathrm{mL}$ GAE) by using gallic acid calibration curve.

\section{Total Flavonoid Compound Determination}

Determination of total flavanoid content of plant extras was carried out by the spectrophotometric method [8]. The mixture contained $100 \mu \mathrm{L}$ E.rigida leaf extract and $100 \mu \mathrm{L}$ of $2 \% \mathrm{AlCl}_{3}$ solution dissolved in methanol. The samples were incubated for $10 \mathrm{~min}$ at room temperatureand their absorbances were measured with a UV-Vis. spectrophotometer at $415 \mathrm{~nm}$. Quercetin $(50-100 \mu \mathrm{g} / \mathrm{mL})$ was used as a standard. The samples were repeated 3 times for each analysis and total flavonoids were calculated using the quercetin standard curve.

\section{E. Tannin Compound Determination}

The method used for tannin determination is the same as the one described for phenolic content [7]. Instead of gallic acid as standard, tannic acid was employed for the preparation of the standard curve and after reading at $760 \mathrm{~nm}$ sample results were presented as tannic acid equivalent (TAE) $\mu \mathrm{g} / \mathrm{mL}$.

\section{F. Silver Nanoparticles Green Synthesis}

The optimization of the nanoparticles was performed by modifying various parameters. Different concentrations of silver nitrate $(1.0,2.0,4.0,6.0,8.0$, and $10 \mathrm{mM})$, E.rigida $(0.04,0.06,0.08,0.1 \%)$, pH (3.0, 5.0, 7.0, 9.0, and 11$)$, temperature $\left(25,37,40,50\right.$ and $\left.80^{\circ} \mathrm{C}\right)$, and the reaction time $(15,30,60,90,120,180$, and $240 \mathrm{~min}$ ) were applied in order to determine the optimum parameters for the AgNPs synthesis using E.rigida leaf extract.

\section{G. Characterization of The Synthesized Er-AgNPs}

The silver nanoparticles obtained by using optimized parameters were characterized using appropriate spectral analysis methods. Absorption spectra of AgNPs solution was monitored by a UV-Vis spectrophotometer (Perkin Elmer Lambda 35 UV/VIS Spectrometer) from 300 to $800 \mathrm{~nm}$. The diluted supernatant ( $1 \mathrm{~mL}$ ) of the ErAgNPs sample was deposited in a quartz cuvette. The size and distribution of the Er- AgNPs was estimated using a Dynamic Light Scattering instrument (DLS, Malvaren Zetasizer Nano) in a polystyrene cuvette. The surface morphology of particles was analyzed using scanning electron microscopy (SEM). 


\begin{tabular}{|c|c|c|}
\hline & $\begin{array}{l}\text { BŞEÜ Fen Bilimleri Dergisi } \\
8(2), 512-522,2021\end{array}$ & $\begin{array}{r}\text { BSEU Journal of Science } \\
\text { https://doi.org/10.35193/bseufbd.843005 }\end{array}$ \\
\hline on & & 2458-7575 (https://dergipark.org.tr/tr/pub/bseufbd) \\
\hline
\end{tabular}

\section{H. Antimicrobial Assay}

Antimicrobial activities of the Er-AgNPs were determined according to the microdilution method [9]. Antimicrobial activity of synthesized AgNP was tested against Staphylococcus aureus (ATCC 25923), Escherichia coli (ATCC 29998), Enterococcus faecium (DSM 13590), Staphylococcus epidermidis (ATCC 12228), Salmonella enteritidis (ATCC 12228), Salmonella typhimurium (ATCC 12228), Listeria monocytogenes (ATCC 25923) and Candida albicans (ATCC 10239) strains. The different pathogens were incubated in Mueller Hinton broth over night. Serial dilutions of the test sample with different concentrations were prepared. AgNPs $(80 \mu \mathrm{L})$ from each dilution were transferred into 96-wells sterile microtitre plates and $20 \mu \mathrm{L}$ of the microbial inocula were then added to obtain a final volume of $100 \mu \mathrm{L}$ in each well. For each dilution series, equal volume $(80 \mu \mathrm{L})$ of the test sample (AgNPs) and Mueller Hinton broth served as negative control while untreated cell suspensions were employed as positive controls.Gentamycin and flucytosine were respectively used as standard antibacterial and antifungal reagents. The plates were incubated at $37^{\circ} \mathrm{C}$ for $24 \mathrm{~h}$. Microbial growth was assessed by eye inspection. MIC was defined as the lowest concentration of the test samples required to inhibit microbial growth after $24 \mathrm{~h}$. The procedure was repeated three times. The results are expressed in $\mu \mathrm{g} / \mathrm{mL}$.

\section{III.RESULTS AND DISCUSSIONS}

\section{A. Phytochemical Analysis of Euporbia rigida Leaf Extract Content}

The results of phytochemical analyses in the extracts of E. rigida leaves are given in Table 1. Phytochemical profiles proved the presence of flavonoid, anthocyanins, phenol, tannins, steroid and quinones. Phytochemicals including anthocyanins, phenols, flavanoids and steroid are thought to be effective in the stabilization and effective capping of silver nanoparticles. [6]. The flavonoid, phenolic, and tannin content of an aqueous extract of E.rigida leaves were found to be $0.086 \% / \mathrm{g}$ leaf, $0.225 \% / \mathrm{g}$ leaf, $0.182 \% / \mathrm{g}$ leaf respectively. E. rigida leaves are a rich source of phytochemicals including anthocyanin, phenol, flavanoid compounds. Thus, theywere believed to be a great tool for the green synthesis process of AgNPs. It has been suggested that, free hydroxyl and carboxylic groups of flavonoids and phenols of the plant are able to bind to the Ag+ surface and trigger the formation of AgNPs while the C-O, C-O-C and C-C groups may function as a stabilizer.

Table 1. Phytochemical profiles of Euporbia rigida leaves

\begin{tabular}{llc}
\hline Phytochemical screening assay & Euorphia rigida extract \\
\hline $\mathbf{1}$ & Tannins test $\left(\mathrm{FeCl}_{3}\right.$ test) & +++ \\
$\mathbf{2}$ & Alkoloids test (Mayer's test) & ++ \\
$\mathbf{3}$ & Flavonoids test (Lead acetate test) & +++ \\
$\mathbf{4}$ & Anthocyanidines test (HCl/ammonia) & + \\
$\mathbf{5}$ & Carbohydrates test (molish's test) & + \\
$\mathbf{6}$ & Phenol test (FeCl ${ }_{3}$ test) & +++ \\
$\mathbf{7}$ & Steroid test (Salkowski test) & ++ \\
$\mathbf{8}$ & Quinones test (conc. $\mathrm{H}_{2} \mathrm{SO}_{4}$ & + \\
$\mathbf{9}$ & Coumarin test & + \\
\hline
\end{tabular}

“+” shows the presence of phytochemicals, "++" shows moderate concentration of phytochemicals , "+++" shows high concentration of phytochemicals

\section{B. Preparation of Silver Nanoparticles}

In this study, E.rigida leaf extract for the synthesis of silver nanoparticles was used. In the natural bioreductive extract environment of E.rigida, silver (I) cations have been found to be reduced to neutral silver (0) type and the colour was observed to become darker as it changed from light yellow to light brown (Figure 1).It is very well known that discolorationis caused by surface plasmon resonance of nanoparticles. The discoloration is mainly due to the stimulation of surface plasmon resonance in metal nanoparticles. The observed discoloration is an indicator of the formation of silver nanoparticles. Nanoparticles are known to originate from superficial plasmon vibrations. Our results were also confirmed by previous studies [10] that reported the formation of silver 
nanoparticles using plant extracts. The change in bioreduction time can be caused by differences in the activity of enzymes present in leaf extract.

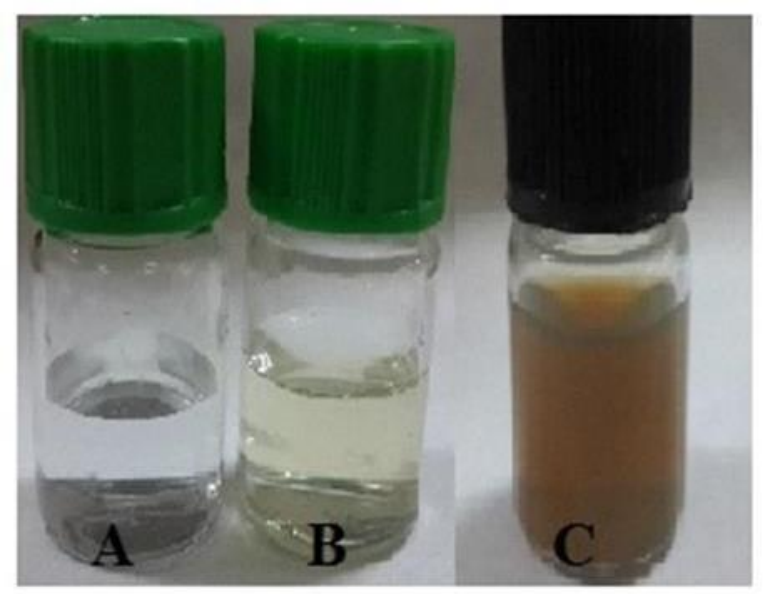

Figure 1. Biosynthesis of silver nanoparticles using E. rigida leaf extract; A) Silver nitrate solution B) E.rigida leaf extract and C) Er-AgNPs

\section{Silver Nanoparticles Green Synthesis}

The reduction of silver nitrate to silver nanoparticle using the plant leaf extract was showed by the colour change in the reaction solutions. Absorption was measured in the $300-800 \mathrm{~nm}$ wavelength range in the UV-visible spectrophotometer. Optimization of experimental conditions is necessary to obtain optimal conditions for the formation of silver nanoparticles. The optimization parameters involved in this study were $\mathrm{pH}$, temperature, incubation period, silver nitrate concentration, and plant concentration.

\section{The Effect of AgNO3 Concentration on Silver Nanoparticle Synthesis}

The effect of $\mathrm{AgNO}_{3}$ concentration on the production of $\mathrm{Ag}$ nanoparticles was assessed by varying $\mathrm{AgNO}_{3}$ concentration. Silver nanoparticles synthesized from $1 \mathrm{mM}$ silver nitrate observed a Plasmon resonance band peak around $429 \mathrm{~nm}$. At $1 \mathrm{mM}$ concentration, a narrow band was observed with increased absorbance, while other concentrations observed a wide peak at $429 \mathrm{~nm}$. The absorption was increased by increasing the concentration of silver ions from $1 \mathrm{mM}$ to $5 \mathrm{mM}$ (Figure 2). Due to the excess of functional groups in leaf extract, the nanoparticle synthesis and small size was begun quickly at $1 \mathrm{mM}$ concentration. The optimization study showed that concentration has a significanteffect on the synthesis of silver nanoparticles. This study concluded that the optimal concentration of $\mathrm{AgNO}_{3}$ for nanoparticles synthesis is $1 \mathrm{mM}$. In similar studies, the increased density was found to cause an increase in the concentration of nanoparticles. Higher concentration of silver nitrate results in a bigger size of the synthesized Er-AgNPs [11]. 


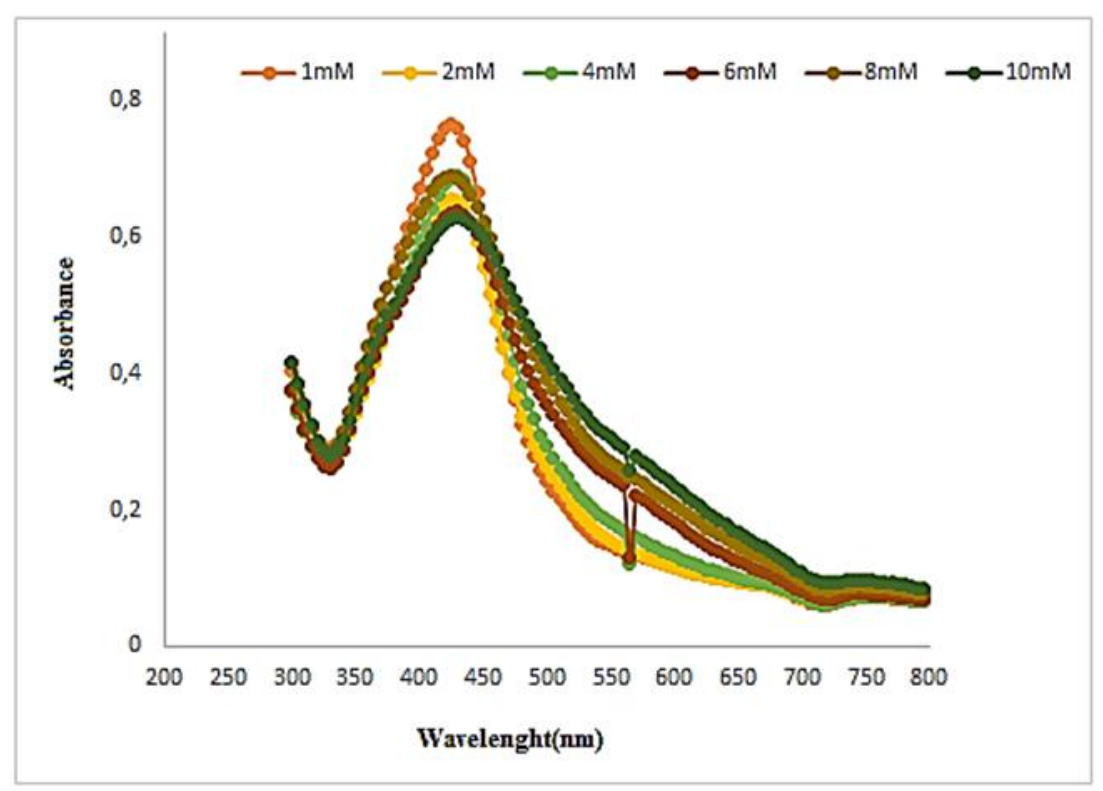

Figure 2. Absorption analysis of the Er-AgNPs synthesized at different concentrations of $\mathrm{AgNO}_{3}$

\section{E. The Effect of Temperature on Silver Nanoparticle Synthesis}

Temperature is one of the important factorson the shape and size of silver nanoparticles. Varying the temperature $\left(20,30,40,50\right.$, and $\left.80^{\circ} \mathrm{C}\right)$ during the synthesis of AgNPs results in a rapid change in the solution color. This is an indication of the increase in the silver salt reduction (Figure 3). The synthesis of nanoparticles increases with increasing the reaction temperature [12]. The broadening peak $(470 \mathrm{~nm})$ was observed at low temperature, which indicatesthe formation of large-sized nanopaticles. The narrow peak $(424 \mathrm{~nm})$ was observed at high temperature $\left(80^{\circ} \mathrm{C}\right)$, which means thatthe small-sized nanoparticleswere formed. Finally, it was concluded thathigher temperature was optimum for nanoparticles synthesis.

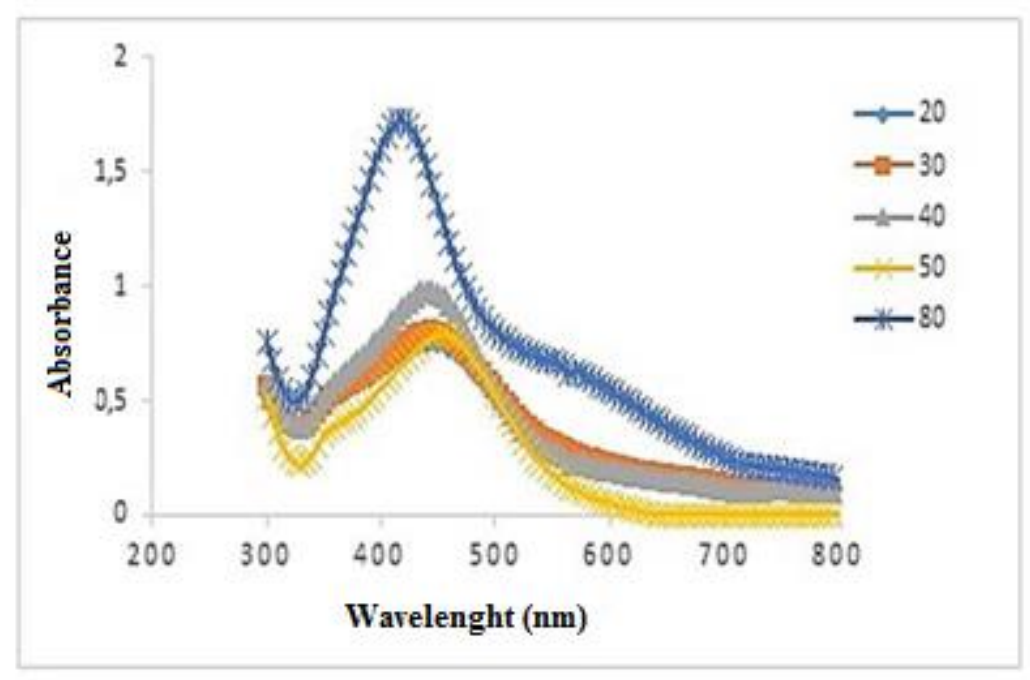

Figure 3. Absorption analysis of the Er-AgNPs synthesized at different temperatures 


\section{F. The Effect of Reaction Time on Silver Nanoparticle Synthesis}

The effect of the reaction time on the formation of silver nanoparticles was investigated and the optimum conditions for the reaction were selected. The UV-Vis absorption of silver nanoparticles obtained from E.rigida leaf extract were taken at different time intervals (Figure 4). The absorption spectra of silver nanoparticles obtained from E. rigida leaf extract was measured and the best SPR peak was observed within $430 \mathrm{~nm}$ at $180 \mathrm{~min}$. It was observed that UV-Vis absorption intensity incrementedasthe reaction time took longer. Reports from the literature indicate that the optimal time is reached when the color is stable and the SPR can be seenin a narrow shape [13].

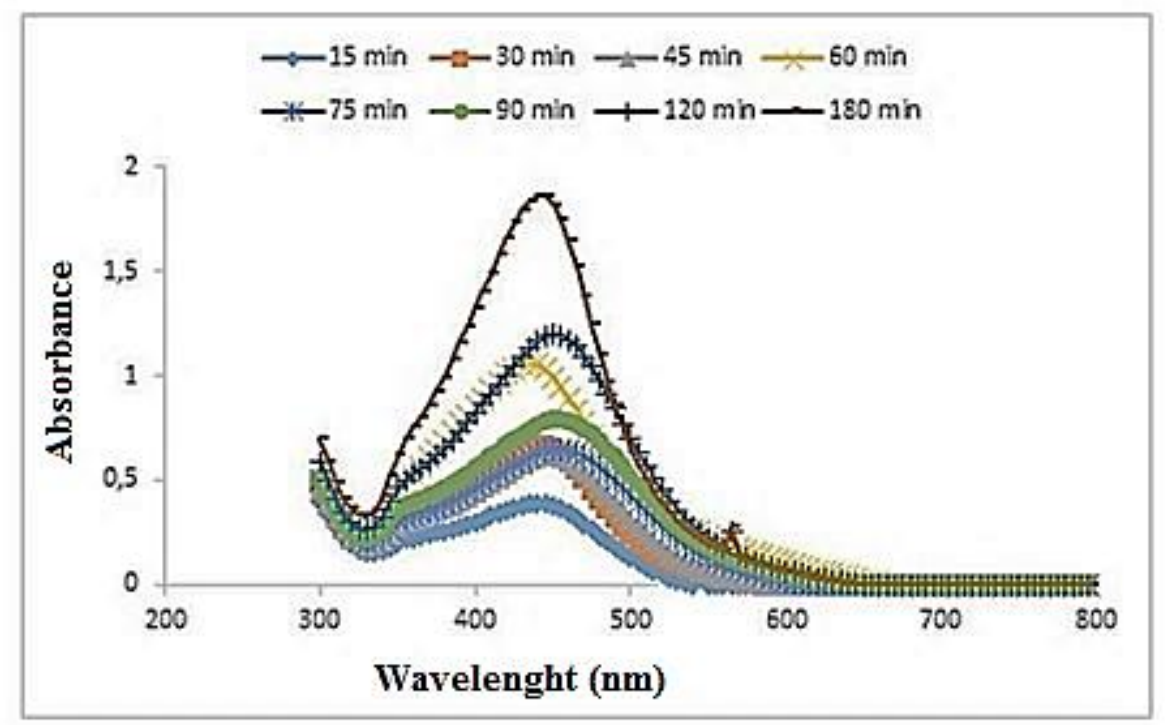

Figure 4. Absorption analysis of the Er-AgNPs synthesized at different contact time

\section{G. The Effect of pH on The Silver Nanoparticle Synthesis}

The influence of $\mathrm{pH}$ on the silver nanoparticles was investigated under different $\mathrm{pH}$ (Figure 5). The colour change of the solution from light yellow to brown showed the formation of Er-AgNPs. The $\mathrm{pH}$ is an important parameter that affects the stability, size and morphology of the nanoparticles. Because $\mathrm{pH}$ has the ability to change the charge of biomolecules, itcan affect their caps and stabilizing ability. At alkaline $\mathrm{pH}(\mathrm{pH}$ 9.0), maximum surface plasmon resonance band of the silver nanoparticles was observed at $420 \mathrm{~nm}$. As the $\mathrm{pH}$ increases from 3 to 9 , the absorption intensity also increases; however, at $\mathrm{pH} 11.0$ the absorbance decreasesagain. The maximum formation of silver nanoparticles was observed at alkaline $\mathrm{pH}$. Nahar et al. also reported that Ag-NPs show maximum stability at the $\mathrm{pH} 9.0$ [14]. 


\begin{tabular}{|c|c|c|}
\hline & $\begin{array}{l}\text { BŞEÜ Fen Bilimleri Dergisi } \\
8(2), 512-522,2021\end{array}$ & $\begin{array}{r}\text { BSEU Journal of Science } \\
\text { https://doi.org/10.35193/bseufbd.843005 }\end{array}$ \\
\hline $\begin{array}{l}\text { BiLECIK SEYH EDE } \\
\text { UNIVERSIT }\end{array}$ & & 2458-7575 (https://dergipark.org.tr/tr/pub/bseufbd) \\
\hline
\end{tabular}

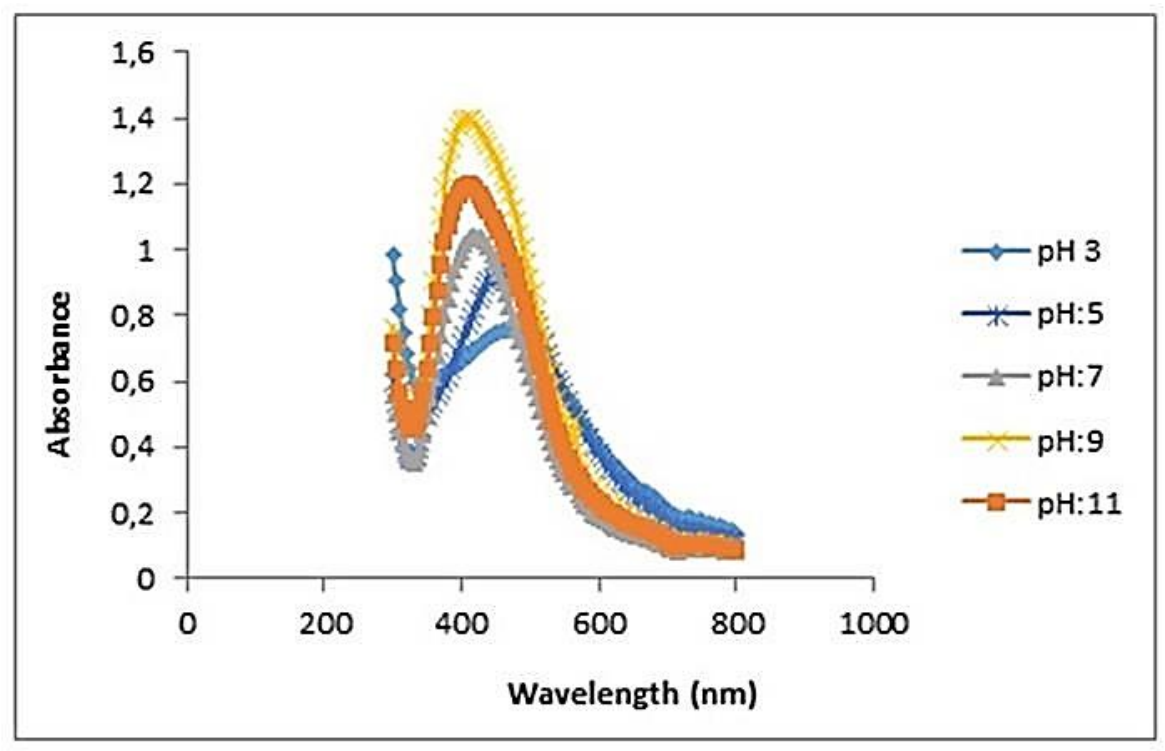

Figure 5. Absorption analysis of the Er-AgNPs synthesized at different $\mathrm{pH}$

\section{H. The Effect of Plant Extract Concentration on Silver Nanoparticle Synthesis}

Biosynthesis of nanosilver particles at different concentrations of E.rigida plant extract ranging bet- ween $0.05 \%$ to $1 \%$ was characterized by UV-visible absorption spectroscopy. Resultsthat areobtained indicate that AgNPs synthesized with the lowest concentration of E.rigida leaf extract was showed absorption band at $434 \mathrm{~nm}$. The concentration $(0.1 \%)$ of plant extract gradually shifts towards low absorption $(434 \mathrm{~nm})$ of the absorption band. However, the absorptionband expands whilethe concentration of plant extract gradually increases. It reverts to significantly higher absorption $(464 \mathrm{~nm})$. It is thought that it may be due to the presence of large amounts of reductantsin the reaction medium (electron-rich phytomolecules). This can cause rapid reduction of Ag ions. Rapid reduction of $\mathrm{Ag}$ ions facilitates further growth of nanoparticles. The absorption band of silver nanoparticle synthesized at highest leaf extract concentration is $464 \mathrm{~nm}$. In this study, it was decided that the optimum plant concentration for synthesizing small sized nanoparticles was $0.1 \%$. Unlike the characteristic peak, another peak was observed at $369 \mathrm{~nm}$ in the absorption spectrum of AgNPs synthesized from $0.25-1 \%$ extract concentration. This is known to be caused by phytomolecules of E.rigida attached to the AgNPs surface as stabilizing ligands [15].

\section{Characterization of The Synthesized Er-AgNPs}

In structural characterization studies of nanoparticles, particle size distributions in solution were studied using the DLS technique. The average particle size was determined to be $86 \mathrm{~nm}$. It supports that nanoparticles are found in small clusters and do not form agglomerate stacks. In terms of particle size, compared to the DLS device, the SEM device gives values closer to reality. In this case, the DLS device gives information about the state of synthesis rather than the particle size. Simultaneously, the zeta potential values of nanoparticles were measured. AgNPs synthesized from euphorbia plant leaf extract were determined to have a zeta potential of $302.3 \mathrm{mV}$. 


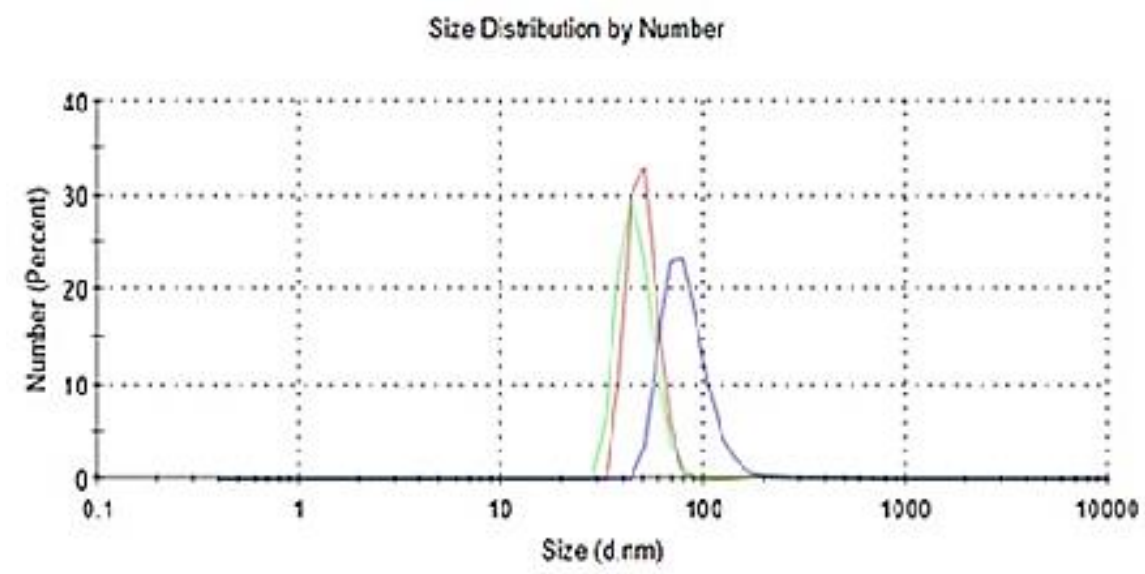

Figure 6. Zeta potential analysis of Er-AgNPs

The SEM results of synthesized Er-AgNPs showed in Figure 7. In the SEM images, the surface morphology of the silver nanoparticles was concluded to show a smooth, equal andspherical structure. It was thought that the reason for thiscircular shape couldbe the different quantity and nature of the capping agent found in the leaf extract used in AgNPs synthesis. The particle size histogram of E.rigidaleaf extract ranged from 50 to $75 \mathrm{~nm}$. Our results have been determined in accordance with previous studies [16]. This result indicatesthat E.rigida leaf extracts can act as a reducing agent in the production of silver nanoparticles. Since the size of the synthesized nanoparticles is less than $100 \mathrm{~nm}$, the suitability of the particles for cell penetration can be mentioned.

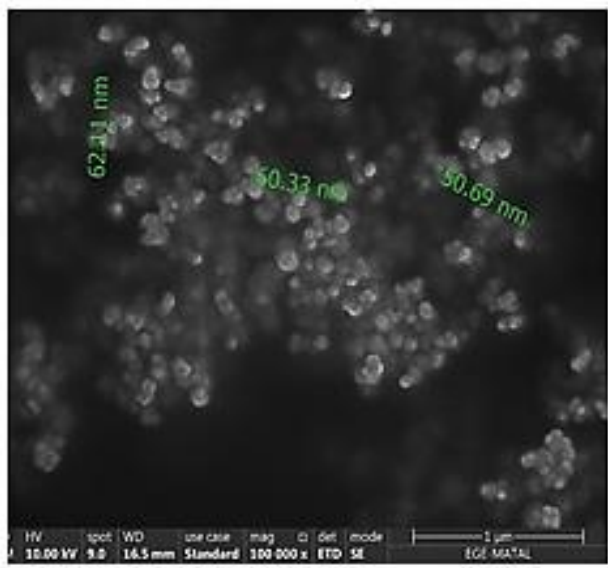

Figure 7. SEM analysis of Er-AgNPs

\section{J. Antimicrobial Activities of the Green Synthesized Er-AgNPs}

The antimicrobial effects of the prepared AgNPs were investigated against Gram-positive and Gramnegativebacteria, anda fungus. The determined MIC values for AgNPs were represented in (Table 2). The result showed thatthe highest antibacterial activity against $E$. faecium and $S$. epidermidiswith MIC values were observed as $125 \mu \mathrm{g} / \mathrm{mL}$. Given the results obtained in the current study and the previously reported results from green chemistry synthesized AgNPs[17,19], it is safe to say that silver NPs are a good option for antibacterial solutions with potential for health and biomedical related fields. The presence of plant biomolecules such as phenolic compounds, flavonoids and terpenoids in the extract, can increase the antimicrobial activity of green synthesized Er-AgNPs. The exact mechanics of antimicrobial activities of the prepared AgNPs are still not fully known [17]. 


\begin{tabular}{|c|c|c|}
\hline & $\begin{array}{l}\text { BŞEÜ Fen Bilimleri Dergisi } \\
8(2), 512-522,2021\end{array}$ & $\begin{array}{r}\text { BSEU Journal of Science } \\
\text { https://doi.org/10.35193/bseufbd.843005 }\end{array}$ \\
\hline $\begin{array}{l}\text { BiLECIK SEYH EDE } \\
\text { UNIVERSIT }\end{array}$ & & 2458-7575 (https://dergipark.org.tr/tr/pub/bseufbd) \\
\hline
\end{tabular}

Table 2. MIC values of ErAgNPs for different microorganisms

\begin{tabular}{llll}
\hline Microorganisms & \multicolumn{3}{c}{ MIC levels $(\boldsymbol{\mu g} / \mathbf{m L})$} \\
\hline Escherichia coli (ATCC29998) & AgNPs & Gentamycin & Flucytosine \\
Staphylococcus aureus (ATCC 25923) & 500 & 15.6 & - \\
Enterococcus faecium (DSM 13590) & 250 & 7.8 & - \\
Staphylococcus epidermidis (ATCC 12228) & 125 & 15.6 & - \\
Salmonella enteritidis (ATCC 13076) & 125 & 7.8 & - \\
Salmonella typhimurium (ATCC 14028) & 250 & 15.6 & - \\
Listeria monocytogenes (ATCC 19111) & 250 & 15.6 & - \\
Candida albicans (ATCC 10239) & 250 & 7.8 & - \\
\hline
\end{tabular}

\section{IV.CONCLUSIONS}

Interest in the green synthesis method as a means of obtainingnanoparticles is increasing. The silver nanoparticles wereproduced by bioreduction methods using aqueous leaves extract of $E$. rigida. The reduction of silver nitrate to silver nanoparticle was approved by UV-vis spectrophotometer, DLS and SEM techniques. Antimicrobial activity assesment of the AgNPs demonstrated a strong antimicrobial activity against importanthuman pathogens (E. coli, S. aureus, E. faecium, S. epidermidis, S. enteritidis, S. typhimurium, L. monocytogenes and C. Albicans) With the increase in nanotechnological research, the synthesized Er-AgNPs will open a new field for the production of biomedical and industrial products and pharmaceutical industry to become more useful.

\section{ACKNOWLEDGEMENT}

The scanning electron microscopy (SEM) measurements for surface morphology of nanoparticles were performed in the Ege University Application and Research Center for Testing and Analysis (EGE-MATAL). I also thank Associate professor Hasan YILDIRIM for kindly providing the plant.

\section{REFERENCES}

[1] Alsaba, M. T., Al Dushaishi, M. F., \& Abbas, A. K. (2020). A comprehensive review of nanoparticles applications in the oil and gas industry. Journal of Petroleum Exploration and Production Tech-nology, 111

[2] Mankad, M., Patil, G., Patel, D., Patel, P., \& Patel, A. (2020). Comparative studies of sunlight mediated green synthesis of silver nanoparaticles from Azadirachta indica leaf extract and its antibacterial effect on Xanthomonas oryzae pv. Arabian Journal of Chemistry, 13(1), 2865-2872.

[3] Zhao, X., Zhou, L., Riaz Rajoka, M.S., Yan, L., Jiang, C., Shao, D., \& Jin, M. (2018). Fungal silver nanoparticles: synthesis, application and challenges. Critical Reviews in Biotechnology, 38(6), 817-835.

[4] Zepon, K.M., Marques, M.S., da Silva Paula, M.M., Morisso, F.D.P., \& Kanis, L. A. (2018). Facile, green and scalable method to produce carrageenan-based hydrogel containing in situ synthesized AgNPs for application as wound dressing. International Journal of Biological Macromolecules, 113, 51-58.

[5] Özbilgin, S. \& Çitoğlu, G. (2012). Uses of some Euphorbia species in traditional medicine in Turkey and their biological activities. Turkish Journal of Pharmaceutical Sciences, 9(2), 241-256.

[6] Jyoti, K., Baunthiyal, M., \& Singh, A. (2016). Characterization of silver nanoparticles synthesized using Urtica dioica Linn. leaves and their synergistic effects with antibiotics. Journal of Radiation Research and Applied Sciences, 9(3), 217-227.

[7] Kocazorbaz, E., Un, R., Erdag, A., \& Zihnioglu, F. (2017). Inhibitory effects of some bryophytes on glutathione-s-transferase. Current Enzyme Inhibition, 13(1), 34-40.

[8] Christel, Q. D. (2000). Phenolic compounds and antioxidant activities of buckwheat (Fagopyrum esculentum Moench) hulls and flour. Journal of Ethnopharmacology, 72, 35-42.

[9] Wang L, Hu C, \& Shao L (2017). The antimicrobial activity of nanoparticles: present situation and prospects for the future. International Journal of Nanomedicine, 12, 1227. 
[10] Aritonang, H. F., Koleangan, H., \& Wuntu, A. D. (2019). Synthesis of silver nanoparticles using aqueous extract of medicinal plants' (Impatiens balsamina and Lantana camara) fresh leaves and analysis of antimicrobial activity. International Journal of Microbiology.

[11] Elbaghdady, K., El-Shatoury, E. I. N. A. S., Abdallah, O., \& Khalil, M. (2018). Biogenic production of silver nanoparticles by Enterobacter cloacae Ism26. Turkish Journal of Biology, 42(4), 319-328.

[12] Qasim Nasar M, Zohra T, Khalil A T, Saqib S, Ayaz M, Ahmad A, \& Shinwari Z K (2019). Seripheidium quettense mediated green synthesis of biogenic silver nanoparticles and their theranostic applications. Green Chemistry Letters and Reviews, 12(3), 310-322.

[13] Balavandy, S. K., Shameli, K., Biak, D. R. B. A., \& Abidin, Z. Z. (2014). Stirring time effect of silver nanoparticles prepared in glutathione mediated by green method. Chemistry Central Journal, 8(1), 11

[14] Nahar, K., Aziz, S., Bashar, M., Haque, M., \& Al-Reza, S. M. (2020). Synthesis and characterization of Silver nanoparticles from Cinnamomum tamala leaf extract and its antibacterial potential. International Journal of Nano Dimension, 11(1), 88-98.

[15] Sathishkumar, M., Sneha, K., \& Yun, Y. S. (2010). Immobilization of silver nanoparticles synthesized using Curcuma longa tuber powder and extract on cotton cloth for bactericidal activity. Bioresource Technology, 101(20), 7958-7965.

[16] Sankar, R., Karthik, A., Prabu, A., Karthik, S., Shivashangari, K.S., \& Ravikumar, V. (2013). Origanum vulgare mediated biosynthesis of silver nanoparticles for its antibacterial and anticancer activity. Colloids and Surfaces B: Biointerfaces, 108, 80-84.

[17] Ayışı̆̆ı, M., Yalçın, T., \& Aktaş, L.Y. (2019). Antimicrobial Potentials of Phyto-synthesized Silver Nanoparticles from Laurus nobilis L.CBU Journal of Science, 15(3), 317-321.

[18] Korkmaz, N., Ceylan, Y., Hamid, A., Karadağ, A., Bülbül, A. S., Aftab, M. N., Çevik, Ö., \& Şen, F. (2020). Biogenic silver nanoparticles synthesized via Mimusops elengi fruit extract, a study on antibiofilm, antibacterial, and anticancer activities. Journal of Drug Delivery Science and Technology, 59, 101864.

[19] Korkmaz, N. (2020). Bioreduction: the biological activity, characterization, and synthesis of silver. Turkish Journal of Chemistry, 44(2), 325. 